\title{
Anti-tumour necrosis factor $\alpha$ therapy for ankylosing spondylitis: international experience
}

\author{
J Braun, J Sieper, M Breban, E Collantes-Estevez, J Davis, R Inman, H Marzo-Ortega, \\ H Mielants
}

Ann Rheum Dis 2002;61 (Suppl III):iii5 1-iii60

See end of article for authors' affiliations

Correspondence to: Dr J Braun, Rheumazentrum Ruhrgebiet, Landgrafenstr.

15, 44652, Herne, and UKBF, Free University,

Berlin, Germany;

j.braun@

rheumazentrum-ruhrgebiet.de
The conventional approach to treatment of patients with spondyloarthritis $(\mathrm{SpA})$, particularly ankylosing spondylitis (AS), has serious limitations, adding a sense of urgency to the evaluation of new treatments for these rheumatic disorders. Tumour necrosis factor $\alpha$ (TNF $\alpha$ ) is a cytokine that has been shown to mediate inflammatory and regulatory activities in SpA and other immune mediated diseases, including other arthritides and inflammatory bowel disease. Positive results have been reported in several international open label and randomised controlled trials of infliximab and etanercept, the two main biological agents targeting $\mathrm{TNF} \alpha$, which have included approximately 300 patients with SpA. Specifically, TNF $\alpha$-directed therapy resulted in significant improvements in disease activity, function, and quality of life in these patients, most of whom had AS and received infliximab. Preliminary evidence from open label, long term extension trials suggests clinical benefit with continued use. Serious side effects were rare and consistent with experience from patient groups receiving infliximab or etanercept treatment for inflammatory bowel disease or rheumatoid arthritis. Together, these findings herald an age of more effective treatment of patients with AS with anti-TNF $\alpha$ and other emerging biological agents.
$\mathrm{T}$ he management of ankylosing spondylitis (AS) with conventional medical treatment has been of limited benefit (see "Conventional treatments for ankylosing spondylitis" within this supplement ( $\mathrm{p}$ iii40)). Treatments for AS need to address the primary aspects of the disorder-that is, inflammatory back pain and stiffness, peripheral arthritis, and enthesopathy. Slowing or regression of disease progression, visualised by radiograph or magnetic resonance imaging (MRI), and improvement in functional ability and quality of life (QoL), are additional desired outcomes. Non-steroidal anti-inflammatory drugs (NSAIDs) often are effective in reducing pain and stiffness but fail to control disease activity or modify the course of the disease. Second line treatment with sulfasalazine may be most effective in early and active AS with peripheral arthritis ${ }^{12}$ and may prevent anterior uveitis, ${ }^{3}$ but has only modest effects in more severe disease and disease with substantial spinal involvement. The efficacy of methotrexate and other disease modifying antirheumatic drugs (DMARDs) has not yet been adequately established in controlled trials of AS. As a result, new treatments are needed to help control this chronic, potentially disabling disorder.

Biological agents blocking the major effector and regulatory cytokine tumour necrosis factor $\alpha$ (TNF $\alpha)$ are among the new treatments currently being investigated in AS. The two major anti-TNF $\alpha$ therapies that have demonstrated efficacy in the treatment of AS are the chimeric monoclonal IgGl antibody infliximab (Remicade; Centocor, Inc, Malvern, PA, USA) and the $75 \mathrm{kDa}$ IgGl receptor fusion protein etanercept (Enbrel; Immunex Corporation, Seattle, WA, USA). In contrast with conventional treatments, these biological compounds target specific inflammatory and immunoregulatory molecules and events affiliated with AS and spondyloarthritis (SpA). Infliximab and etanercept have been used to treat patients with AS in several open pilot and randomised controlled studies conducted in Europe and North America, which have included laboratory, clinical, radiographic, and MRI end points. This review provides the pathogenetic and clinical rationale for the use of these agents in the treatment of AS, evidence of their immunomodulatory effects in patients with the disease, and an overview of findings from the previously mentioned international clinical studies.
RATIONALE FOR USE OF ANTI-TNF $\alpha$ THERAPY IN AS

Several observations strongly implicate TNF $\alpha$ in the pathogenesis of AS and suggest the therapeutic potential of anti-TNF $\alpha$ agents in this rheumatic disorder. Significantly higher TNF $\alpha$ serum levels have been found in patients with AS than in patients with non-inflammatory back pain, although the cytokine concentration did not correlate with laboratory or clinical measures of disease activity. ${ }^{4}$ More recently, high amounts of TNF $\alpha$ messenger RNA $^{5}$ and protein ${ }^{6}$ were detected in sacroiliac joint biopsy specimens from patients with AS (fig 1). Sacroiliitis, like enthesitis, is almost pathognomonic for AS. ${ }^{7}$

The relationship between SpA and inflammatory bowel disease provides further evidence of a role for TNF $\alpha$ in AS. Microscopic and macroscopic bowel inflammation resembling early Crohn's disease has been found in $20-60 \%$ of patients with spinal and peripheral arthritis in AS and other forms of $\mathrm{SpA}^{8 .}{ }^{9}$ Gut lesions in patients with AS can be clinically silent and are more often chronic than acute, particularly in those with peripheral arthritis. The potential for shared pathogenic processes in inflammatory bowel disease and SpA has been suggested by a study conducted by May et $a l^{10}$ who found identical $\mathrm{T}$ cell expansions in the colon mucosa and synovium of a patient with enterogenic SpA. Synovial T cell clones were expanded throughout the colon and peripheral blood and, when stimulated in vitro, produced various cytokines, including TNF $\alpha$. In vitro studies have shown that production of TNF $\alpha$ is increased in the mucosa of patients with Crohn's disease, ${ }^{11}{ }^{12}$ and controlled clinical studies have documented the efficacy of the anti-TNF $\alpha$ monoclonal antibody infliximab

Abbreviations: AS, ankylosing spondylitis; BASDAI, Bath AS Disease Activity Index; BASFI, Bath AS Functional Index; BASGI, Bath AS Global Index; CRP, C reactive protein; $C T$, computed tomography; DMARD, disease modifying antirheumatic drug; ESR, erythrocyte sedimentation rate; IFN $\gamma$, interferon $\gamma$; IL, interleukin; MRI, magnetic resonance imaging; NSAID, non-steroidal anti-inflammatory drug; PsA, psoriatic arthritis; QoL, quality of life; RA, rheumatoid arthritis; SF-36, Short Form-36; SpA, spondyloarthritis; TNF $\alpha$, tumour necrosis factor $\alpha$; VAS, visual analogue scale 

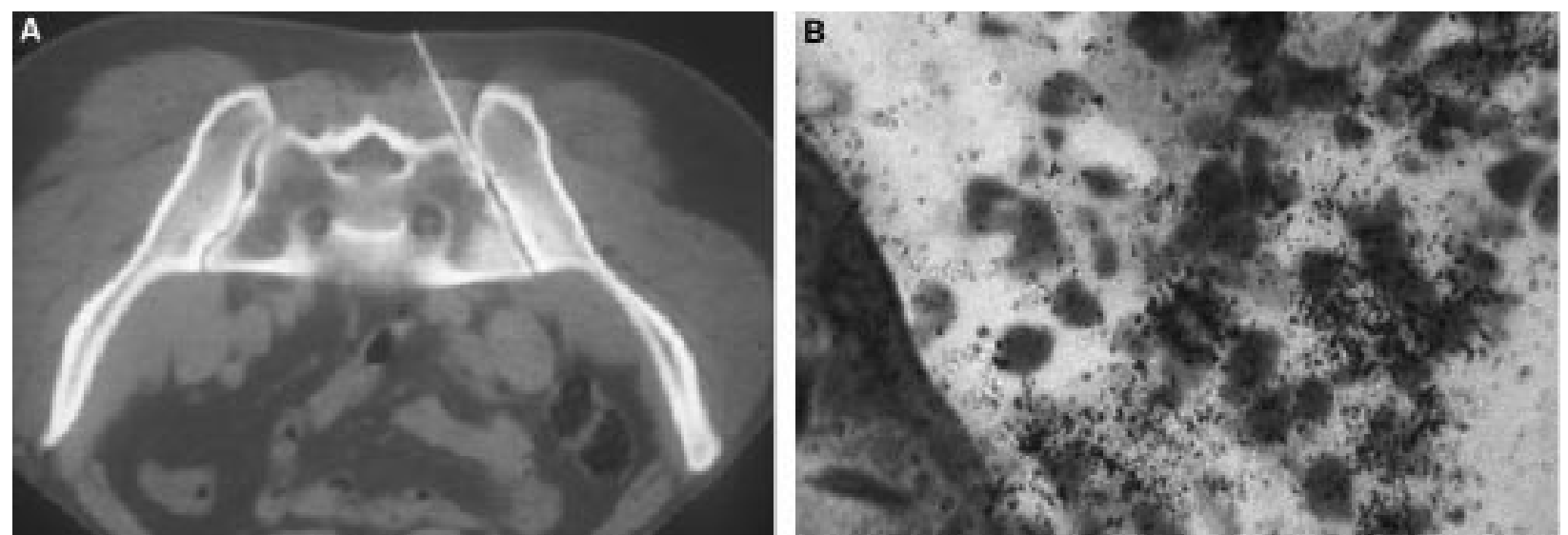

Figure 1 (A) Computed tomography (CT) guided sacroiliac biopsy specimens from patients with active AS; (B) provided specimens with TNF $\alpha$ mRNA (black spots). ${ }^{5}$ Adapted and reprinted, with permission from the authors and Wiley-Liss, Inc, a subsidiary of John Wiley and Sons, Inc, from reference 5. Copyright (C) 1995 Wiley-Liss.

for both acute and maintenance treatment in this inflammatory bowel disorder. ${ }^{13-15}$ Paradoxically, the anti-TNF $\alpha$ fusion protein etanercept, given at a dose of $25 \mathrm{mg}$ twice weekly, did not effectively induce clinical response in a recently reported placebo controlled trial of patients with active Crohn's disease ${ }^{16}$ Whether this is because of the known pharmacological differences between etanercept and infliximab (for example, recognition of membrane bound TNF by infliximab and lymphotoxin binding by etanercept) is not known.

In addition, increased levels of TNF $\alpha$ are found in other arthritides, including psoriatic arthritis (PsA) $)^{17-19}$ and rheumatoid arthritis (RA).$^{20}$ Although RA is certainly pathogenetically different from SpA and the pathogenic processes underlying the development of RA and SpA have not been clearly established, TNF $\alpha$ may have a pivotal role in both types of inflammatory arthritis. Clinical trials testing the anti-TNF $\alpha$ agents infliximab and etanercept have demonstrated their efficacy in $\mathrm{PsA}^{21-24}$ and RA, ${ }^{25}{ }^{26}$ with evidence of halted or slowed progression of joint damage in RA. ${ }^{27}$

Taken together, these findings provide a strong argument favouring a role for TNF $\alpha$ in AS and suggest that anti-TNF $\alpha$ agents might be effective therapeutic options in this SpA. The latter hypothesis has been further supported by studies of the immunomodulatory effects of these agents in $\mathrm{SpA}$ and confirmed by the results of clinical trials in groups with AS.

\section{IMMUNOMODULATORY EFFECTS OF ANTI-TNF $\alpha$ THERAPY IN AS}

SpA seems to be associated with impairment in the balance of helper T cells subtypes 1 and 2 (Th1 and Th2), demonstrated by reduced T cell production of interleukin 2 (IL2), interferon $\gamma($ IFN $\gamma)$, and TNF $\alpha$, and increased synthesis of IL10 in the peripheral blood compartment and at the site of the synovial membrane in patients with the disorder ${ }^{29-34}$ In a study quantifying $\mathrm{T}$ cell cytokine production at the single cell level in patients with AS and healthy controls, Rudwaleit et al noted a significantly lower percentage of TNF $\alpha$ positive $\mathrm{T}$ cells in human leucocyte antigen (HLA)-B27 positive patients with AS and HLA-B27 positive healthy controls compared with HLA-B27 negative healthy controls. ${ }^{29}{ }^{34}$ HLA-B27 is strongly associated with AS, occurring in approximately $90 \%$ of white AS populations. ${ }^{35}$ Interestingly, low secretion of TNF $\alpha$, but no difference in the secretion of other Thl or Th2 cytokines, was detected in patients with early reactive arthritis compared with controls and was significantly correlated with a more chronic course of the disease. ${ }^{36}$ HLA-B27 positive patients with reactive arthritis had lower TNF $\alpha$ secretion than HLA-B27 negative patients. The lower TNF $\alpha$ expression at the cellular level may be explained by the occurrence of systemic down regulation, while local concentrations may be high.
An impaired Thl profile also has been reported in gut lamina propria lymphocytes from patients with $\mathrm{SpA} .^{33}$ Van Damme et al found lower IFN $\gamma$ and IL2 production in this lymphocyte compartment and an increased fraction of IL $10^{+} \mathrm{CD}^{+}{ }^{+} \mathrm{CD}^{-}$cells. $^{33}$ Using the same methodology, these researchers recorded a similar $\mathrm{CD} 3$ cytokine profile in patients with Crohn's disease. ${ }^{37}$ These findings suggest that impaired Thl capacity plays a part in the pathogenesis of SpA, possibly through failure of effective bacterial elimination at the initiation of the disease, and that gut mucosal lymphocytes also may actively participate in its development. TNF $\alpha$ appears to be abundantly present at the sites of inflammation, making it a legitimate target of biological treatment.

In two open label pilot studies, anti-TNF $\alpha$ therapy has been shown to reverse abnormalities in Thl cytokine secretion in SpA. ${ }^{62}$ Treatment with three infusions of infliximab in 20 patients with SpA induced a rapid and sustained increase in IFN $\gamma$ and IL2 levels and a rapid but transient decrease in IL10 levels in patients with high baseline values, resulting in levels similar to those in healthy control patients. ${ }^{32}$ Similarly, in patients with AS treated with infliximab, investigators observed a significant increase in the percentage of $\mathrm{CD}^{+}$ TNF $\alpha$ and IFN $\gamma$ producers after treatment. ${ }^{6}$ In contrast, in a German placebo controlled study of anti-TNF $\alpha$ therapy, a clear reduction was found in the percentage of $\mathrm{CD}^{-}$and $\mathrm{CD}^{+} \mathrm{T}$ cells producing TNF $\alpha$ and IFN $\gamma$ after in vitro stimulation. ${ }^{38}$ Additional studies are needed to clarify this issue.

Further insight into the immunomodulatory mechanisms of anti-TNF $\alpha$ therapy in SpA has been provided by the histological analysis of synovial biopsy tissues from eight patients with treatment resistant SpA, including three patients with AS who were treated with infliximab. ${ }^{39}$ At week 12, analysis showed reductions in the synovial layer thickness and CD55 synoviocytes, the vascularity of the synovial sublining layer, and endothelial expression of vascular cell adhesion molecule 1 , but not in other adhesion molecules (for example, intercellular adhesion molecule 1, platelet endothelial cell adhesion molecule 1, and E-selectin). The number of neutrophils and $\mathrm{CD}^{+} 8^{+}$macrophages in the sublining layer also was decreased at week 12, but no change was seen in the overall degree of inflammatory infiltration because of an increase in $\mathrm{CD}_{2} 0^{+}$ lymphocytes and plasma cells. Surprisingly, some of these effects, including the adhesion molecule expression, $\mathrm{T}$ cell infiltration, and B cell infiltration, may conflict with those reported in RA, suggesting that anti-TNF $\alpha$ therapy may have different immunomodulatory mechanisms in SpA and RA. 
Table 1 Clinical studies of anti-TNF $\alpha$ agents in SpA/AS

\begin{tabular}{|c|c|c|c|c|c|c|c|c|c|}
\hline Study & $\begin{array}{l}\text { Site } \\
\text { design }\end{array}$ & Study & $\begin{array}{l}\text { Patients } \\
\text { (n) }\end{array}$ & Age (y) & $\begin{array}{l}\text { Disease } \\
\text { duration }(y)\end{array}$ & Dose & $\begin{array}{l}\text { Treatment } \\
\text { duration }\end{array}$ & Outcome parameters & $\begin{array}{l}\text { \% Reduction in } \\
\text { median BASDAl } \\
\text { score }\end{array}$ \\
\hline $\begin{array}{l}\text { Infliximab } \\
\text { Brandt et al, } \\
2000^{40}\end{array}$ & $\begin{array}{l}\text { Berlin, } \\
\text { Germany }\end{array}$ & $\mathrm{OL}$ & AS (11) & 36 (mean) & 5 (median) & $\begin{array}{l}5 \mathrm{mg} / \mathrm{kg} \text { IV } \\
\text { at weeks } 0 \text {, } \\
2 \text {, and } 6\end{array}$ & $3 \mathrm{mo}$ & $\begin{array}{l}\text { - Clinical/functional } \\
\text { assessments (e.g. } \\
\text { BASDAI, BASFI, } \\
\text { BASMI) } \\
\text { - QoL assessment } \\
\text { (SF-36) } \\
\text { - Inflammatory } \\
\text { markers } \\
\text { - MRI }\end{array}$ & $63 \%(12 w k)$ \\
\hline $\begin{array}{l}\text { Van den Bosch } \\
\text { et al, } 2000^{42}\end{array}$ & $\begin{array}{l}\text { Ghent, } \\
\text { Belgium }\end{array}$ & $\mathrm{OL}$ & $\begin{array}{l}\operatorname{SpA}(21) \\
{[\mathrm{AS}(11)]}\end{array}$ & 49 (median) & 17 (median) & $\begin{array}{l}5 \mathrm{mg} / \mathrm{kg} \text { IV } \\
\text { at weeks } 0 \text {, } \\
2 \text {, and } 6\end{array}$ & $\begin{array}{l}84 \mathrm{~d} \text {, plus } 1 \text { y } \\
\text { follow up }\end{array}$ & $\begin{array}{l}\text { - Global disease } \\
\text { activity assessments } \\
\text { - Axial assessments } \\
\text { (e.g., BASDAI, } \\
\text { BASFI, BASMI) } \\
\text { - Peripheral arthritis } \\
\text { assessments (e.g., } \\
\text { TJC, SJC) }\end{array}$ & $82 \%(84 d)$ \\
\hline $\begin{array}{l}\text { Stone et al, } \\
2001^{45}\end{array}$ & $\begin{array}{l}\text { Toronto, } \\
\text { Canada }\end{array}$ & $\mathrm{OL}$ & AS (21) & 38 (median) & 9 (median) & $\begin{array}{l}5 \mathrm{mg} / \mathrm{kg} \text { IV } \\
\text { at weeks } 0 \text {, } \\
2 \text {, and } 6\end{array}$ & 14 wk & $\begin{array}{l}\text { - Clinical/functional } \\
\text { assessments (e.g., } \\
\text { BASDAI, BASFI) } \\
\text { - Clinimetrics } \\
\text { - Inflammatory } \\
\text { markers } \\
\text { - MRI }\end{array}$ & $93 \%$ (14 wk) \\
\hline $\begin{array}{l}\text { Spanish } \\
\text { Spondyloarthritis } \\
\text { Study Group, } \\
2002^{46}\end{array}$ & Spain & $\mathrm{OL}$ & $\begin{array}{l}\mathrm{SpA}(26) \\
{\left[\mathrm{AS}^{*}\right.} \\
(18)]\end{array}$ & 44 (mean) & 15 (mean) & $\begin{array}{l}5 \mathrm{mg} / \mathrm{kg} \text { IV } \\
\text { at weeks } 0, \\
2,6,14,22, \\
\text { and } 30\end{array}$ & $30 w k$ & $\begin{array}{l}\text { - Clinical/functional } \\
\text { assessments (e.g., } \\
\text { BASDAI, BASFI, } \\
\text { pain VAS) } \\
\text { - QoL assessment } \\
\text { (SF-36) } \\
\text { - Inflammatory } \\
\text { markers }\end{array}$ & $\begin{array}{l}57 \%(14 w k) ; \\
45 \%(30 \text { wk); } \\
\text { (p<0.001 at both } \\
\text { end points) }\end{array}$ \\
\hline $\begin{array}{l}\text { Breban et al, } \\
2002^{47}\end{array}$ & France & $\mathrm{OL}$ & AS (50) & 36 (mean) & 15 (mean) & $\begin{array}{l}5 \mathrm{mg} / \mathrm{kg} \text { IV } \\
\text { at weeks } 0 \text {, } \\
2 \text {, and } 6\end{array}$ & $6 \mathrm{mo}$ & $\begin{array}{l}\text { - Global disease } \\
\text { activity assessments } \\
\text { - Clinical/functional } \\
\text { functional } \\
\text { assessments (e.g., } \\
\text { BASDAl, BASFI, } \\
\text { pain VAS) } \\
\text { - Inflammatory } \\
\text { markers }\end{array}$ & $76 \%$ (8wk) \\
\hline $\begin{array}{l}\text { Maksymowych } \\
\text { et al, } 2002^{48}\end{array}$ & $\begin{array}{l}\text { Canada } \\
\text { RCT }\end{array}$ & & 21 (AS) & 42.5 (mean) & 13.8 (mean) & $\begin{array}{l}3 \mathrm{mg} / \mathrm{kg} \text { IV } \\
\text { at weeks } 0 \text {, } \\
2 \text {, and } 6 \text {, } \\
\text { then q } 2 \text { mo }\end{array}$ & $52 \mathrm{WK}$ & $\begin{array}{l}\text { - Clinical / functional } \\
\text { assessments } \\
\text { (BASDAI, BASFL, } \\
\text { BASGI, BASMI) } \\
\text { - MRI (6 patients) }\end{array}$ & $\begin{array}{l}54.85 \% \text { (mean } \\
14 \text { wk; } p<0.001)\end{array}$ \\
\hline $\begin{array}{l}\text { Braun et al, } \\
2002^{49}\end{array}$ & Germany & $\mathrm{RCT} / \mathrm{OL}$ & AS (70) & 39 (mean) & 15 (median) & $\begin{array}{l}5 \mathrm{mg} / \mathrm{kg} \text { IV } \\
\text { at weeks } 0 \text {, } \\
2 \text {, and } 6 \text {, } \\
\text { then q } 6 \text { wk }\end{array}$ & $\begin{array}{l}12 \text { wk (RCT) } \\
54 \text { wk (OL) }\end{array}$ & $\begin{array}{l}\text { - Clinical/functional } \\
\text { assessments (e.g., } \\
\text { BASDAI, BASFI, } \\
\text { BASMI, ASAS, pain } \\
\text { NRS) } \\
\text { - QoL assessment } \\
\text { (SF-36) } \\
\text { - Inflammatory } \\
\text { markers }\end{array}$ & $\begin{array}{l}49 \% \text { v } 10 \% \\
\text { (mean values at } \\
12 \text { wk; } \\
p<0.0001) ; 56 \% \\
(54 w k \text { ), } \\
p<0.0001\end{array}$ \\
\hline $\begin{array}{l}\text { Van den Bosch } \\
\text { et al, } 2002^{51}\end{array}$ & Belgium & $\mathrm{RCT} / \mathrm{OL}$ & $\begin{array}{l}\operatorname{SpA}(40) \\
{[A S(19)]}\end{array}$ & $\begin{array}{l}47.3 \text { (placebo) } \\
46 \text { (infliximab) }\end{array}$ & $\begin{array}{l}8 \text { (placebo) } \\
6.5 \\
\text { (infliximab) }\end{array}$ & $\begin{array}{l}5 \mathrm{mg} / \mathrm{kg} \text { IV } \\
\text { at weeks } 0 \text {, } \\
2 \text {, and } 6 \text {, } \\
\text { then q } 6 \text { wk }\end{array}$ & $\begin{array}{l}12 \text { wk (RCT) } \\
54 \text { wk (OL) }\end{array}$ & $\begin{array}{l}\text { - Global disease } \\
\text { activity assessments } \\
\text { - Clinical functional } \\
\text { assessments (e.g., } \\
\text { BASDAl, BASFI, } \\
\text { pain VAS) } \\
\text { - Inflammatory } \\
\text { markers }\end{array}$ & $\begin{array}{l}86 \% \text { v } 18 \%(8) \\
\text { wk); ( } p=0.002, \\
\text { infliximab v } \\
\text { placebo) } \\
55 \% \text { v } 5 \%(12 \\
\text { wk); ( }=0.002, \\
\text { infliximab } v \\
\text { placebo) }\end{array}$ \\
\hline
\end{tabular}

\section{EFFECTS OF ANTI-TNF $\alpha$ THERAPY ON SPINAL} MANIFESTATIONS AND PERIPHERAL ARTHRITIS IN PATIENTS

\section{WITH AS}

Several open label and randomised controlled studies have evaluated the efficacy of the anti-TNF $\alpha$ agents infliximab and etanercept on the axial manifestations and peripheral arthritis of AS (table 1).

\section{Infliximab}

Open label studies

In a single centre, open label pilot study conducted in Berlin, Brandt et al showed that infliximab was very effective in controlling disease activity in patients with severe active AS. ${ }^{40}$ Eleven patients who had AS for a median of five years received 
Table 1 continued

\begin{tabular}{|c|c|c|c|c|c|c|c|c|c|}
\hline Study & $\begin{array}{l}\text { Site } \\
\text { design }\end{array}$ & Study & $\begin{array}{l}\text { Patients } \\
\text { (n) }\end{array}$ & Age (y) & $\begin{array}{l}\text { Disease } \\
\text { duration }(y)\end{array}$ & Dose & $\begin{array}{l}\text { Treatment } \\
\text { duration }\end{array}$ & Outcome parameters & $\begin{array}{l}\% \text { Reduction in } \\
\text { median BASDAI } \\
\text { score }\end{array}$ \\
\hline \multicolumn{10}{|l|}{ Etanercept } \\
\hline $\begin{array}{l}\text { Marzo-Ortega et } \\
\text { al, } 2000^{52}\end{array}$ & UK & $\mathrm{OL}$ & $\begin{array}{l}\operatorname{SpA}(10) \\
{[\mathrm{AS}(7)]}\end{array}$ & 37 (mean) & 12 (mean) & $\begin{array}{l}25 \mathrm{mg} \mathrm{SC} \\
\text { twice } \\
\text { weekly }\end{array}$ & $6 \mathrm{mo}$ & $\begin{array}{l}\text { - Global disease } \\
\text { activity assessments } \\
\text { - Clinical/functional } \\
\text { assessments (e.g., } \\
\text { BASDAl, BASFI, } \\
\text { spinal pain VAS) } \\
\text { - Entheseal counts } \\
\text { - Peripheral arthritis } \\
\text { assessments (e.g., } \\
\text { TJC, SJC) } \\
\text { - QoL assessment } \\
\text { (ASQoL) } \\
\text { - MRI }\end{array}$ & $79 \%$ \\
\hline $\begin{array}{l}\text { Gorman et al, } \\
2002^{53}\end{array}$ & US & $\mathrm{RCT}, \mathrm{OL}$ & AS (40) & 39 (mean) & 14 (mean) & $\begin{array}{l}25 \mathrm{mg} \mathrm{SC} \\
\text { twice } \\
\text { weekly }\end{array}$ & $\begin{array}{l}4 \mathrm{mo}(\mathrm{RCT}) \\
6 \mathrm{mo}(\mathrm{OL})\end{array}$ & $\begin{array}{l}\text { - Global disease } \\
\text { activity assessments } \\
\text { - Clinical/functional } \\
\text { assessments (eg, } \\
\text { BASFI, ASAS, } \\
\text { morning stiffness, } \\
\text { spinal mobility, } \\
\text { nocturnal spinal } \\
\text { pain VAS) } \\
\text { - Peripheral arthritis } \\
\text { assessments (e.g., } \\
\text { TJC, SJC) } \\
\text { - Modified } \\
\text { Enthesopathy Index } \\
\text { - QoL assessment } \\
\text { (SF-36) }\end{array}$ & $\begin{array}{l}51 \% \vee 3 \%(4 \\
\text { mo)t; }(p=0.001 \\
\text { etanercept } v \\
\text { placebo) }\end{array}$ \\
\hline
\end{tabular}

*All patients with AS had total ankylosis.

†Median improvement in BASFI.

AS, ankylosing spondylitis; ASAS, Assessments in Ankylosing Spondylitis; ASQoL, Ankylosing Spondylitis Quality of Life; BASDAI, Bath Ankylosing Spondylitis Disease Activity Index; BASFI, Bath Ankylosing Spondylitis Functional Index; BASGI, Bath Ankylosing Spondylitis Global Index; BASMI, Bath Ankylosing Spondylitis Metrology Index; IV, intravenous; MRI, magnetic resonance imaging; NRS, numerical rating scale; OL, open label trial; QoL, quality of life; RCT, randomised controlled trial; SC, subcutaneous; SF-36, Short Form Health Survey 36; SJC, swollen joint count; SpA, spondyloarthritis; TJC, total joint count; VAS, visual analogue scale.

three infusions of infliximab, $5 \mathrm{mg} / \mathrm{kg}$, at weeks 0,2 , and 6 . DMARDs, other immunosuppressant drugs, and corticosteroids were withdrawn before the administration of infliximab, but NSAIDs were given concomitantly as needed. One patient withdrew from the study because of urticaria. Among the remaining 10 patients, nine improved rapidly and significantly, as measured by the Bath AS Disease Activity Index (BASDAI) $(\mathrm{p}=0.001)$. The positive effect occurred as early as one day after the first infusion and, in eight of 10 patients, persisted until week 12 (six weeks after the final infusion). After four weeks, the median improvement in the BASDAI was $70 \%$. Spinal pain, fatigue, and morning stiffness were markedly improved, as well as assessments of peripheral arthritis. In the QoL assessment and measured using the 36 item Short Form Health Survey (SF-36), significant improvement was achieved in median values of six of nine subconcepts. The one year data from this study suggest continuing clinical benefit. ${ }^{41}$

An additional pilot trial with infliximab was performed at a single centre in Belgium in 21 patients with active SpA, including 11 patients with AS (three with only axial disease, seven with associated peripheral arthritis, and one with concomitant PsA). ${ }^{42}$ These patients underwent the same therapeutic regimen as that in the previous German study; they continued receiving stable doses of NSAIDs and corticosteroids during the trial. Rapid and significant improvement in spinal pain was seen in seven of 11 patients after the first infusion $(\mathrm{p}<0.05)$, which was sustained after the induction regimen with maintenance infusions every 14 weeks (table 2 ). At day 84, patients with axial disease had a median improvement of $82 \%$ in the BASDAI. Peripheral parameters were assessed in 18 patients who had at least one manifestation of peripheral arthritis or enthesitis. At day 14, morning stiffness and pain were significantly decreased compared with baseline $(p \leqslant 0.001)$, with significant reductions in tender and swollen joint counts from day 3 onward. Among the 19 patients who completed the one year follow up phase, receiving $5 \mathrm{mg} / \mathrm{kg}$ infliximab every 14 weeks, all disease manifestations were significantly improved throughout the period with retreatment. ${ }^{43}$ In an increasing number of patients, symptoms recurred before the subsequent infusion but always disappeared after the re-administration of infliximab. Through the second year of follow up, increasing the dose to $10 \mathrm{mg} / \mathrm{kg}$ did not prevent the reappearance of symptoms. However, changing to a regimen of $5 \mathrm{mg} / \mathrm{kg}$ every 10 weeks resulted in the maintenance of clinical response. ${ }^{44}$

Stone et al recently reported the findings from an open label, single centre Canadian study of infliximab in 21 patients with active AS in whom conventional treatment had failed..$^{45}$ Patients received the standard induction regimen of inflixi$\mathrm{mab}, 5 \mathrm{mg} / \mathrm{kg}$, at weeks 0,2 , and 6 . Concomitant drugs, including NSAIDs, methotrexate, sulfasalazine, and corticosteroids, were continued at stable doses throughout the study. Among the 18 patients who were evaluated at week 14, the investigators found a $>75 \%$ median improvement in functional variables - that is, BASDAI, Bath AS Functional Index (BASFI), Health Assessment Questionnaire, fatigue, and spinal and total body pain. Infliximab was effective in all patients, with the most dramatic response being achieved by patients with shorter disease duration and better baseline clinimetric scores.

Two similar but multicentre pilot studies have been conducted assessing infliximab in patients with active refractory AS in Spain and France. In the Spanish study, ${ }^{46}$ infliximab 
Table 2 Assessments at baseline and days 14, 42, and 84 after infliximab treatment ${ }^{42}$

\begin{tabular}{|c|c|c|c|c|}
\hline Parameter & Baseline & Day 14 & Day 42 & Day 84 \\
\hline \multicolumn{5}{|c|}{ Global disease activity assessments $(n=21)$} \\
\hline Patient (0-100) & 57 & $23 * * *$ & $11 * * *$ & $10 * * *$ \\
\hline Physician (0-100) & 57 & $23^{* * *}$ & $11 * * *$ & $10 * * *$ \\
\hline \multicolumn{5}{|l|}{ Axial assessments $(n=11)$} \\
\hline Morning stiffness (min) & 90 & $15^{* *}$ & $10 * *$ & $5^{* *}$ \\
\hline BASDAI $(0-100)$ & 62.4 & $18.3^{* *}$ & $9.5^{* *}$ & $11.3^{* *}$ \\
\hline BASFAI (0-100) & 77.4 & $29.4^{* *}$ & 13.1 ** & 22.3 * * \\
\hline Spinal pain (0-3) & 2 & 1 & 0 * & $0 *$ \\
\hline \multicolumn{5}{|l|}{ Peripheral assessments $(n=18)$} \\
\hline Morning stiffness (min) & 90 & $5 * * *$ & $10 * *$ & $5 * * *$ \\
\hline Tender joint count (0-68) & 6 & $2 * * *$ & $0 * * *$ & $0 * * *$ \\
\hline Swollen joint count (0-66) & 3.5 & $1 * * *$ & $0 * * *$ & $0 * * *$ \\
\hline
\end{tabular}

$5 \mathrm{mg} / \mathrm{kg}$ was given to 26 patients with severe SpA at weeks 0 , $2,6,14,22$, and 30. Eighteen patients with AS were included in this group, all of whom had total ankylosis. Patients were permitted to receive acetaminophen as a rescue analgesic, NSAIDs, and corticosteroids during the study, but not DMARDs. Infliximab treatment resulted in a rapid and significant decrease in clinical disease activity, with clinical response observed after the initial infusion and maintained with subsequent infusions. At weeks 14 and 30, patients demonstrated 57\% $\quad(\mathrm{p}<0.001)$ and $45 \% \quad(\mathrm{p}<0.001)$ median improvement in the BASDAI, respectively. Pain, measured using a visual analogue scale (VAS), was reduced by $37 \%$ $(\mathrm{p}<0.001)$ and $29 \%(\mathrm{p}<0.001)$ at these times, respectively. Increases were seen in all nine SF-36 measurements, reaching statistical significance in three subconcepts $(p<0.05)$. The investigators noted that the clinical responses in these patients with SpA, although more moderate than those previously reported, were none the less remarkable given the severity of their disease (that is, $69 \%$ had complete spinal fusion, or "bamboo spine").

The French experience further supports the dramatic efficacy of this anti-TNF $\alpha$ therapy in axial AS. ${ }^{47}$ Breban et al evaluated 50 patients with active, refractory, axial AS but no peripheral arthritis or extra-articular manifestations-for example, uveitis or inflammatory bowel disease, at the time of study entry. NSAIDs were continued at stable doses, but DMARDs were discontinued three months before entry. After treatment with infliximab, patients improved significantly in all measures of disease activity and function at week 8 $(\mathrm{p}<0.0001)$, with greater than $70 \%$ median improvement in global pain and the BASDAI. Maximal improvement was seen as early as two weeks after the first infusion and within 12 weeks in $>80 \%$ of patients.

In another recent open trial, 21 consecutive patients with AS ( 17 men, four women) in Canada, 13 with active peripheral synovitis, mean age 42.5 years (range 24-66), mean disease duration 13.8 years (range 3-26), started intravenous infliximab treatment $3 \mathrm{mg} / \mathrm{kg}$ at weeks 0,2 , and 6 and every 2 months. Intention to treat analysis was performed with a mean follow up of 48 weeks (range 10-77). Four patients withdrew, two for serious adverse events (septic osteomyelitis and severe hypersensitivity after three and two infusions, respectively). Three patients required an increased dose to 5 $\mathrm{mg} / \mathrm{kg}$ after 14 weeks. Efficacy data were available on 17 patients at 14 weeks; mean BASDAI improved significantly from baseline $(6.2)$ to 14 weeks $(2.8)(p<0.001)$, with 10 patients (59\%) showing at least 50\% improvement (range 0-99.6\%). Significant reduction in mean BASFI (43.4\%; $\mathrm{p}<0.001$ ), Bath Ankylosing Spondylitis Global Index (BASGI) $(44 \% ; p=0.001)$, erythrocyte sedimentation rate (ESR) $(55 \%$; $\mathrm{p}<0.001)$, and C reactive protein (CRP) levels $(63.5 \% ; \mathrm{p}=0.01)$ was evident. Complete remission of peripheral joint disease was seen in 5/11 (45\%) patients evaluated at 14 weeks, and maximal rate of MRI defined gadolinium augmentation was significantly decreased $(p=0.04)$. Follow up data on eight patients completing one year of treatment showed continued efficacy at a dose of $3 \mathrm{mg} / \mathrm{kg}$ every eight weeks. Infliximab appears to be effective and well tolerated for both axial and peripheral joint disease in a subgroup of patients with AS, which still needs to be defined, even at lower doses than those examined to date. ${ }^{48}$

\section{Randomised controlled trials}

Two randomised placebo controlled studies evaluating infliximab in patients with AS have been recently published. In a German multicentre study, ${ }^{49} 70$ patients with active AS were randomly allocated to receive either infliximab $5 \mathrm{mg} / \mathrm{kg}$ or placebo at weeks 0, 2, and 6; clinical and laboratory assessments were performed at week 12. After the three month controlled phase, an open label extension was conducted, with all patients receiving infliximab $5 \mathrm{mg} / \mathrm{kg}$ every six weeks until week 48 and final evaluation being performed at week 54 . In the controlled trial, $53 \%$ of patients in the infliximab group had a greater than $50 \%$ improvement in disease activity at week 12, measured by the BASDAI (fig 2A), compared with $9 \%$ in the placebo group $(p<0.0001)$. According to the more rigorous Assessments in Ankylosing Spondylitis (ASAS) Working Group criteria, which require improvement in at least three of four domains (physical function, pain, patient global, and inflammation), with no worsening in the fourth domain, the proportion of patients receiving infliximab who reached greater than $50 \%$ improvement approached 50\% (fig 2B). In addition, a significantly greater percentage of infliximab treated patients achieved partial remission $(20.6 \%)$ at weeks 2,6 and 12 , according to the ASAS criteria, compared with placebo treated patients. Significant improvements were also seen in the infliximab group in function (BASFI; $<<0.0001$ ), spinal mobility ( Bath AS Metrology Index (BASMI); $\mathrm{p}=0.002$ ), and QoL (4/8 SF-36 subconcepts; $\mathrm{p}<0.0001)$. Preliminary data from the 54 week extension phase suggest that the clinical benefits associated with short term infliximab treatment are maintained over time with continued treatment. ${ }^{50}$ Patients who received infliximab during the controlled study phase had a sustained clinical response up to 54 weeks, whereas those who were switched from placebo to infliximab treatment rapidly achieved similar improvements. ${ }^{50}$

The second randomised placebo controlled study, conducted in Belgium, enrolled 40 patients with SpA, including 19 patients with AS. ${ }^{51}$ Patients were randomly allocated to receive infliximab $5 \mathrm{mg} / \mathrm{kg}$ or placebo, given in the same loading regimen described in the previous study. Concomitant NSAIDs and corticosteroids at stable doses were allowed, but DMARDs 

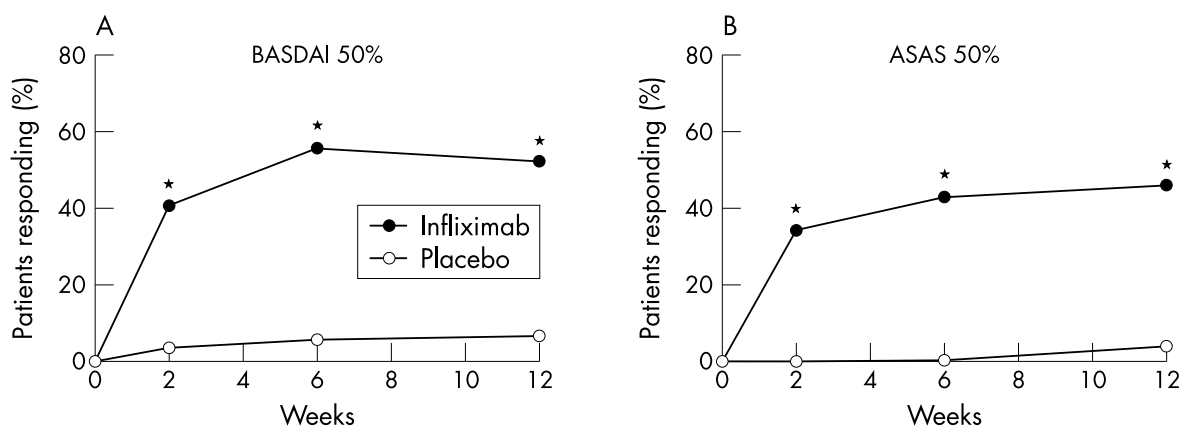

Figure 2 Response among patients with AS treated with placebo $(n=35)$ or infliximab $5 \mathrm{mg} / \mathrm{kg}(\mathrm{n}=34)$ at weeks 0,2 , and 6 . (A) $>50 \%$ Improvement in BASDAl; (b) $>50 \%$ improvement according to the original ASAS Working Group criteria. ${ }^{49}$ * $p<0.0001 ; p$ values were calculated by Fisher's exact test. Adapted and reprinted, with permission from the authors and Elsevier Science, from reference 49. Copyright (C) 2002 by Elsevier Science.
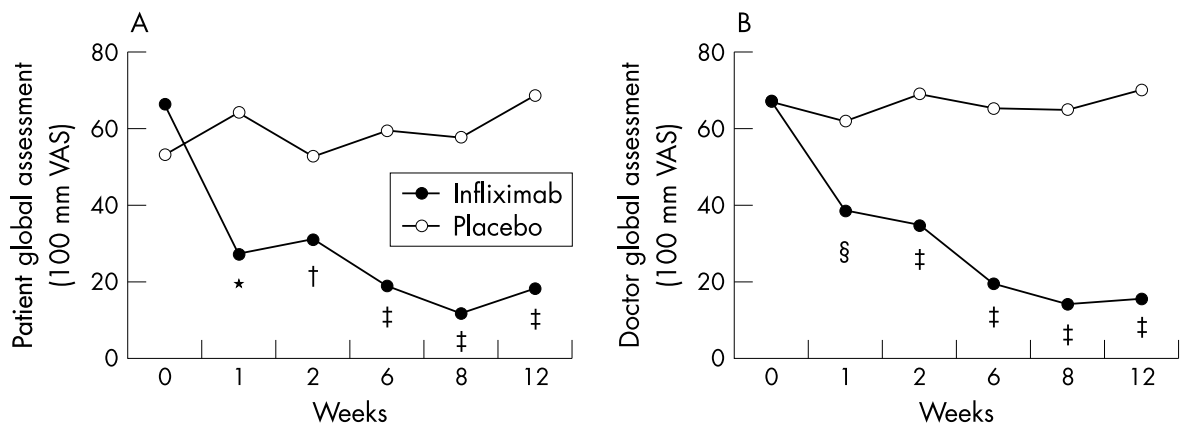

Figure 3 (A) Patient and (B) doctor global assessments of disease activity on a $100 \mathrm{~mm}$ VAS among patients with SpA receiving placebo $(\mathrm{n}=20)$ or infliximab $5 \mathrm{mg} / \mathrm{kg}$ at weeks 0,2 , and $6(\mathrm{n}=20) .{ }^{51}{ }^{*} \mathrm{p}=\mathrm{NS} ; \dagger p \leqslant 0.05 ; \ddagger p \leqslant 0.001 ; \xi p \leqslant 0.01$. Adapted and reprinted, with permission from the authors and Wiley-Liss, Inc, a subsidiary of John Wiley and Sons, Inc, from reference 51. Copyright @ 2002 Wiley-Liss.

were discontinued. The initial three month controlled investigation was followed by a one year open label follow up. In the infliximab treatment group, the investigators observed a significant effect $(p \leqslant 0.001 v$ placebo) on the doctor and patient global assessments of disease activity on a $100 \mathrm{~mm}$ VAS, which served as the study's primary end points, from two weeks and six weeks, respectively, and continuing up to week 12 (fig 3). BASDAI and assessments of peripheral arthritis were significantly improved at 12 weeks in patients receiving infliximab compared with those who received placebo $(\mathrm{p} \leqslant 0.01$ and $\mathrm{p}=0.001 v$ baseline, respectively). Significant clinical improvement in all disease manifestations was maintained with anti-TNF $\alpha$ therapy over the one year follow up period. ${ }^{44}$

\section{Etanercept}

Open label study

In a single centre study conducted in the United Kingdom, Marzo-Ortega et al treated 10 patients with refractory SpA, including seven patients with AS. ${ }^{52}$ All patients had active axial disease; the majority had peripheral joint disease $(n=7)$ and enthesitis $(n=9)$. Etanercept $25 \mathrm{mg}$ was given subcutaneously twice weekly for six months. Corticosteroids and sulfasalazine were discontinued before study entry, but methotrexate was continued in six patients throughout the study. At week 24, all patients demonstrated significant improvement in standard clinical, function, and QoL assessments (table 3 ). Improvements of $79 \%$ and $38 \%$ in BASDAI and BASFI scores, respectively, were reported from baseline to week 24 . Enthesitis also resolved or improved in all patients.

Randomised controlled study

In a single centre, randomised, double blind, placebo controlled study conducted in the United States, 40 patients with active AS without complete spinal fusion received either subcutaneous etanercept $25 \mathrm{mg}$ or placebo for four months. ${ }^{53}$
Table 3 Assessments at baseline and day 14 after etanercept treatment $(n=10)^{52}$

\begin{tabular}{llll}
\hline Parameter & Baseline & Week 24 & $\mathrm{p}$ Value \\
\hline $\begin{array}{l}\text { Global disease activity assessments } \\
\quad \text { Patient (0-100) }\end{array}$ & 70 & 3 & 0.005 \\
$\quad \begin{array}{l}\text { Physician (0-100) } \\
\text { Axial assessments }\end{array}$ & 60.5 & 3 & 0.005 \\
$\quad$ BASDAI (0-10) & 6.25 & 1.3 & 0.005 \\
BASFAl (0-10) & 7.05 & 4.35 & 0.008 \\
$\quad$ Spinal pain (day; 0-100) & 63.5 & 10 & 0.008 \\
$\quad$ Spinal pain (night; 0-100) & 71.5 & 4 & 0.008 \\
Peripheral assessments & & & \\
$\quad$ Early morning stiffness (min) & 120 & 2.5 & 0.008 \\
$\quad$ Tender joint count (0-68) & 6 & 0 & 0.046 \\
$\quad$ Swollen joint count (0-66) & 0.5 & 0 & 0.043 \\
Enthesopathy (0-100) & 62 & 3 & 0.008 \\
ASQoL (0-18) & 14 & 3 & 0.005 \\
\hline
\end{tabular}

Values are the median.

Patients were permitted to continue receiving stable doses of baseline AS drugs, including NSAIDs, corticosteroids, and DMARDs, during the controlled study period. Response was defined as $\geqslant 20 \%$ improvement in at least three of five primary outcome measures (that is, duration of morning stiffness, degree of nocturnal spinal pain, BASFI, patient global assessment, and swollen joint count), one of which needed to be duration of morning stiffness or degree of nocturnal spinal pain, without worsening in the other measures. Seventy five per cent of patients in the etanercept group achieved a response at day 112 , compared with $30 \%$ of those in the placebo group $(\mathrm{p}=0.01))$. Response was observed early (by day 28) and maintained over four months, reaching statistical significance at three of the four month points (fig 4). Analysis of the individual primary outcomes showed significant 


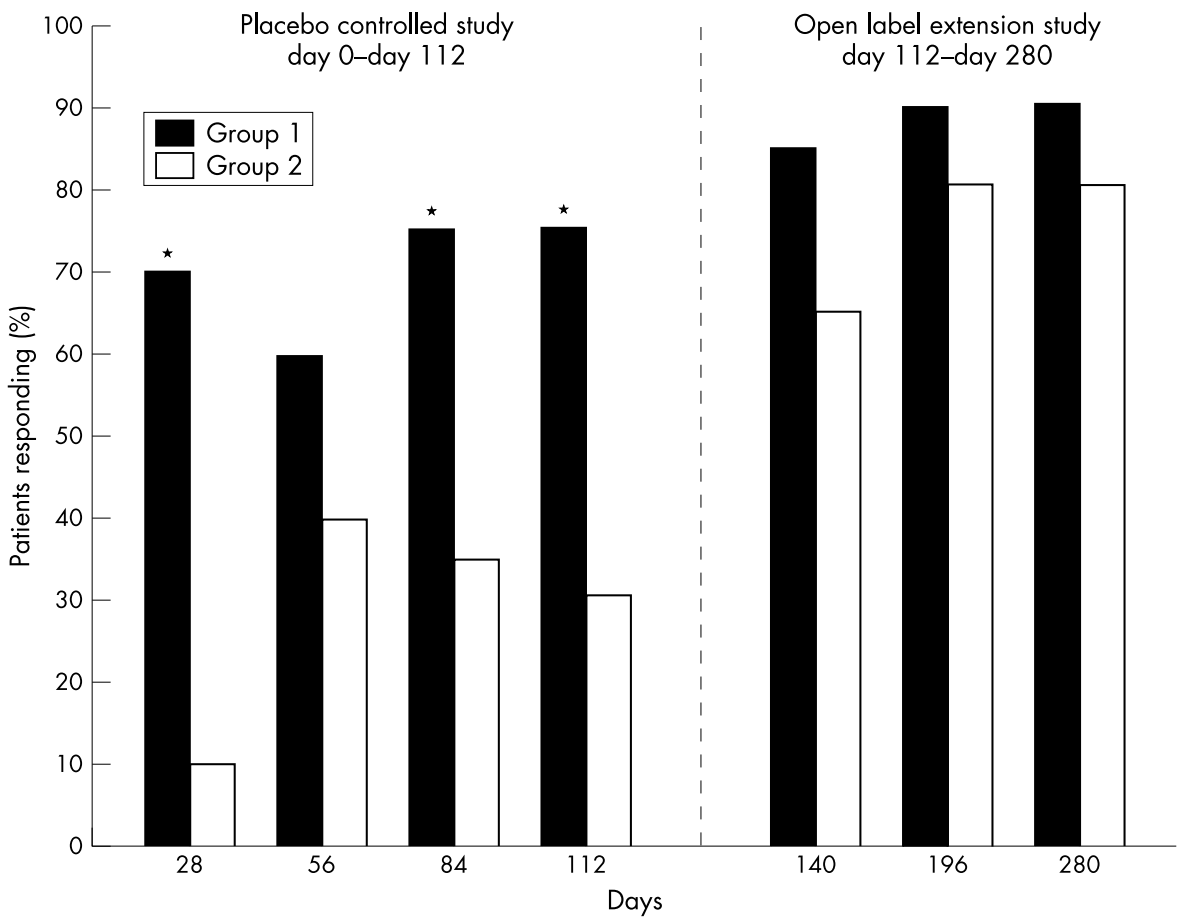

Figure 4 Percentage of patients achieving a clinical response. Group 1 received etanercept injections throughout both studies. Group 2 received placebo injections from day 0 to day 112 , then etanercept injections from day 112 to day 280 . Clinical response defined as at least $20 \%$ improvement in three of five outcome measures. ${ }^{*} \mathrm{p}=0.01$.

improvement at four months in the duration of morning stiffness $(p<0.001)$, nocturnal spinal pain $(p<0.001)$, the BASFI $(\mathrm{p}<0.001)$, and patient global assessment $(\mathrm{p}<0.001)$. Swollen joint counts were lower in etanercept treated patients than in placebo treated patients, but the difference was not statistically significant.

Thirty eight patients from this controlled study were enrolled into a subsequent six month open label extension study of etanercept. ${ }^{53}$ Preliminary data demonstrate a durable response in $>80 \%$ of patients who either continued to receive etanercept or switched from placebo to active treatment. Assessments of all disease manifestations, including function, pain, stiffness, global disease activity, peripheral arthritis, entheses, spinal mobility, and QoL, remained significantly better after six months. During the open label study, patients were permitted to decrease or stop AS drugs. Sixty six per cent of all patients stopped or decreased at least one of their AS treatments by the end of the trial.

\section{EFFECTS OF ANTI-TNF $\alpha$ THERAPY ON SPINAL DISEASE PROGRESSION VISUALISED BY MRI}

Detection of disease progression in mild to moderate AS may require as long as two years with conventional imaging by radiograph. ${ }^{54-56}$ However, MRI has been successfully used to visualise acute sacroiliitis, spondylitis, and spondylodiscitis in patients with SpA in recent studies. ${ }^{57}{ }^{58}$ In contrast with radiographic imaging, which can show the results of inflammation, bony changes, and ankylosis, MRI can detect acute spinal inflammation.

MRI has been used to investigate the impact of anti-TNF $\alpha$ therapy on axial, peripheral, and entheseal disease in patients with AS. Braun et al recently assessed sacroiliac and spinal MRI changes in 20 patients with AS before and after treatment with infliximab. ${ }^{49}$ MRI scans after treatment showed resolution of the sacroiliitis and marked improvement in spondylitis, as exemplified by one of the patients (fig 5). A new scoring system was used for spinal MRI (ASspiMRI), which includes an activity score (0-6) that assesses bone marrow oedema by short tau inversion recovery (STIR) and enhancement after gadolinium-diethylenetriamine pentaacetic acid (Gd-DTPA) by scoring $0-3$ and, in addition, erosions with signs of active inflammation by scoring 4-6 according to size, while the chronicity score (0-6) assesses sclerosis, erosions (score 1-3), small and big syndesmophytes (score 3-4), partial fusion (score 5), and ankylosis (score 6 ) by using $T_{1}$ sequences (minimal score $=0$, maximal $=144$ for all three techniques). In correlation with clinical improvement, there was significant regression of spinal inflammation of patients with active AS treated with infliximab $5 \mathrm{mg} / \mathrm{kg}$ as assessed by the new MRI scoring system by two independent readers (Braun $\mathrm{J}$, submitted).

In some of the other studies spinal inflammation was also compared before and after treatment with the TNF $\alpha$ blocker. In the study of Stone et $\mathrm{al}^{45}$ gadolinium-enhanced MRI imaging showed significant changes in both axial and peripheral joints with infliximab treatment. In the open label trial of etanercept in $\mathrm{SpA}^{52}$ scoring was performed on paired MRI scans of entheseal lesions in the lumbar and cervical spine and peripheral joints at baseline and week 24 . Thirty eight of 44 lesions $(86 \%)$ either resolved completely or improved after treatment, and no new lesions developed.

\section{SIDE EFFECTS OF ANTI-TNF $\alpha$ THERAPY}

Adverse side effects are the greatest concern with new treatments that are apparently highly effective. There are clearly side effects to be considered in patients treated with anti-TNF $\alpha$ agents. Reports of adverse drug events are reported derived from various sources, including clinical studies, cases reported to regulatory agencies, data reported by drug manufacturers, unpublished cases reported individually or in clusters, and personal experience. Each reporting source has advantages as well as shortcomings. For example, clinical studies are controlled and randomised, but a selected patient group is followed up for a limited period of time. Reports to regulatory agencies are relevant because they reflect how the product is used in practice, but they are uncontrolled and may lead to either underestimation or overestimation of the true 

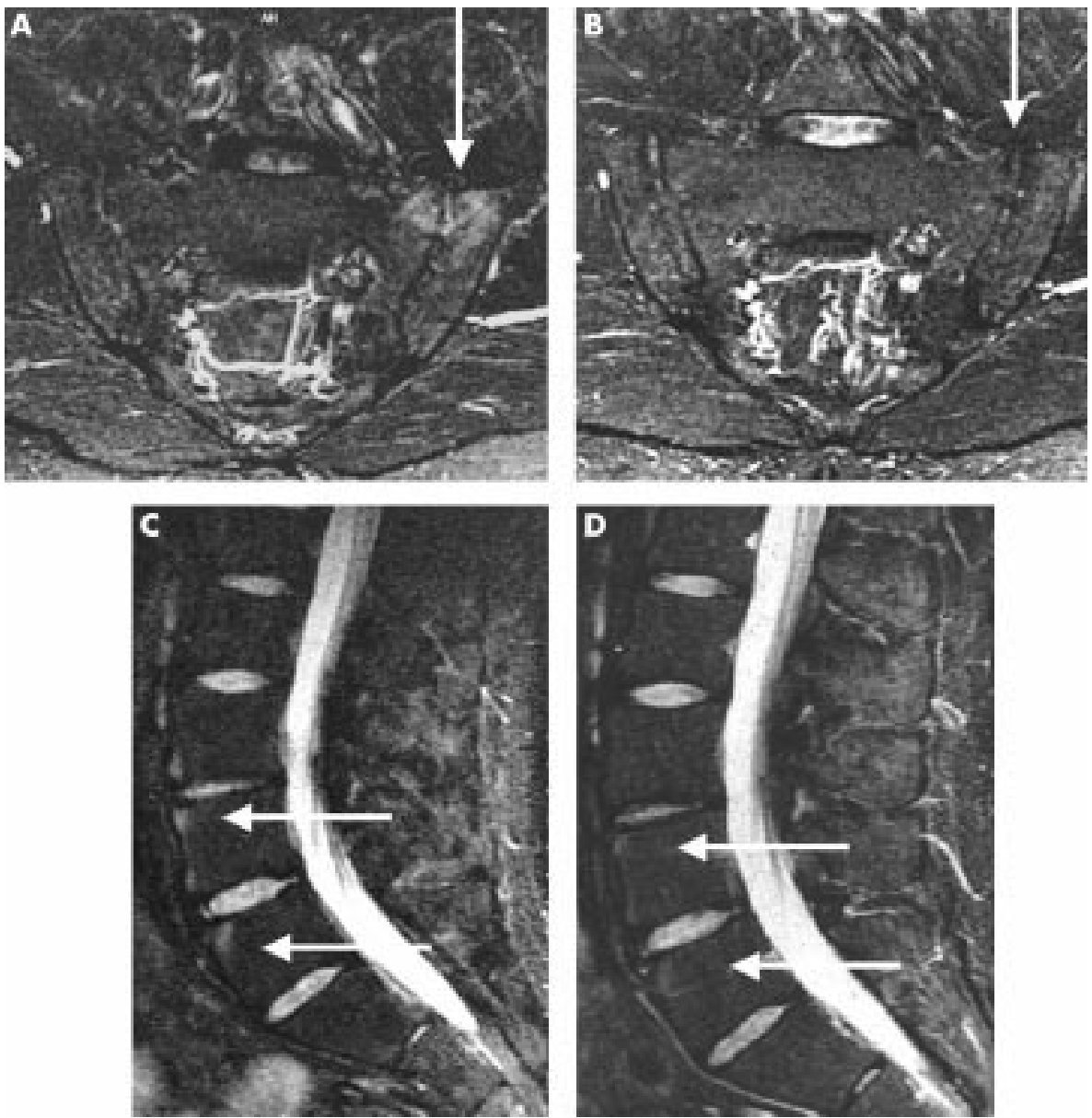

Figure 5 Sacroiliac joints (SIJ) before (A) and three months after $(B)$ the start of infliximab treatment. Sacoiliitis located in the ventral part of the left SIJ is seen in a $T_{1}$ sequence after administration of gadolinium-DTPA ( $A$, arrow) but not, using the same technique at the follow up examination ( $B$, arrow). The spinal MRI before treatment shows spondylitis anterior at vertebrae L2-4 at the lumbar spine (C, arrows), which cannot be seen three months later ( $D$, arrows). ${ }^{49}$ These previously unpublished images are provided courtesy of Dr Matthias Bollow, Augusta Krankenhaus, Bochum and Charitè, Humboldt University, Berlin, Germany.

risk and reporting bias. Data from manufacturers are often comprehensive but may be influenced by financial interests. Case reports and anecdotal experiences may or may not be relevant but can incite overreaction because personal experience is involved. Thus, the aggregate of these different sources of information should be considered when drawing valid conclusions about adverse side effects.

In the case of anti-TNF $\alpha$ agents, such conclusions are still difficult because of limited data and experience. However, the early experience with anti-TNF $\alpha$ therapy has identified seven types of adverse events that seem to be of particular concern: (a) infections, including sepsis and tuberculosis; (b) malignancies such as lymphoma; (c) haematological disorders such as anaemia and pancytopenia; $(d)$ demyelinating disorders and neuropathy; (e) exacerbation of congestive heart failure; $(f)$ production of autoantibodies and autoimmune responses; and $(g)$ infusion or injection and hypersensitivity reactions. Two cases of tuberculosis were reported in randomised placebo controlled investigations of infliximab in $\mathrm{SpA} .^{49}{ }^{51}$ One case involved a 65 year old man treated with prednisolone (10 $\mathrm{mg} /$ day) for PsA. Because he had no history of pulmonary disease, a purified protein derivative test was not performed. He presented with general malaise, high spiking fever, marked increase in ESR and CRP values, but no respiratory symptoms. Mediastinal adenopathy and nodular lesions in the liver and spleen were evident from a computed tomography (CT) scan. Lymph nodule biopsy after mediastinoscopy showed characteristic lesions of tuberculosis. The overall risk of anti-TNF $\alpha$ therapy, however, appears to be small. Immunocompromised and geriatric patients, and those with identifiable comorbidities, are at increased risk of severe side effects. Patients with cardiac insufficiency should not be treated with anti-TNF $\alpha$ agents. Most adverse events seem to be associated with this drug class rather than with individual agents. However, tuberculosis has occurred more frequently among patients treated with infliximab, and there seems to be a higher incidence of demyelinating disease and cytopenia among etanercept treated patients. Both types of sequelae are apparently quite rare.

\section{CONCLUSIONS}

Recent international experience with the anti-TNF $\alpha$ monoclonal antibody infliximab and TNF $\alpha$ soluble receptor compound etanercept clearly suggests that these biological agents are effective in treating patients with AS. Nearly 300 people with SpA, the majority having AS and receiving infliximab treatment, have been evaluated in controlled and open label studies with consistently positive results. Short term benefits have included significant improvements in disease activity, function, and QoL in treatment resistant AS. Long term investigations are continuing, but early reports indicate maintained response for periods of one to two years. Adverse effects data from the SpA studies of infliximab and etanercept seem to be consistent with those reported previously in studies of RA and Crohn's disease.

Serious adverse events, including severe infections (for example, tuberculosis), lupus-like disease, and allergy, were rare, but need to be considered. TNF $\alpha$ is a cytokine that has an 
essential role in fighting microbes, particularly intracellular bacteria. Although additional information is needed about the possible risk for tuberculosis and other infections with anti-TNF $\alpha$ therapy, recommendations about the performance of tuberculin skin testing before infliximab treatment should be carefully considered. Answers to questions about possible predictors of response to anti-TNF $\alpha$ therapy, optimal dosing, and timing of the start of treatment in the disease course are also required from future studies. Increased attention should be focused also on the ability of anti-TNF $\alpha$ therapy to alter the structural biology of the spine, taking advantage of more sophisticated imaging technology to learn more about the disease's natural history and its potential modification with pharmacological treatment.

The often dramatic efficacy of anti-TNF $\alpha$ therapy in such immune mediated inflammatory disorders as SpA, RA, and inflammatory bowel disease has increased interest in the development of other potentially beneficial biological agents, such as interleukin 1 receptor antagonist. The latter biological treatment has been proved to be effective in $\mathrm{RA}^{59}$ but has yet to be tested in AS. Discovery of the pathogenic relationship between inflammation of the gut and synovium has resulted in the identification of several new therapeutic targets, including specific adhesion molecules, macrophage subsets, and chemokines. Some of the treatments that are clinically effective in Crohn's disease result in limited mucosal healing, ${ }^{60}$ whereas others, such as azathioprine ${ }^{61}$ and infliximab, ${ }^{62}$ induce both clinical remission and substantial mucosal healing. Because the interaction between gut bacteria and the immune system may play a part in the pathogenesis of AS, treatments that can heal mucosal gut lesions may be of particular interest for the treatment of AS. Although it is too early to speculate about the potential usefulness of other pathogenic targets, it is clear that anti-TNF $\alpha$ therapy represents an essential advance in SpA treatment that has allowed more thorough understanding of disease mechanisms and may lead the way for the introduction of other profoundly effective therapeutic options.

\section{Authors' affiliations}

J Braun, Rheumazentrum Ruhrgebie, UKBF, Free University, Berlin, Germany

J Sieper, Department of Gastroenterology and Rheumatology, UKBF, Free University, Berlin, Germany

M Breban, Institut de Rhumatologie, Department of Immunology, Hôpital Cochin, Paris, France

E Collantes-Estevez, Department of Rheumatology, Hospital

Universitario Reina Sofia, Cordoba, Spain

J Davis, University of California, San Francisco, San Francisco,

California, USA

R Inman, University of Toronto, Toronto, Canada

H Marzo-Ortega, Rheumatology Research Unit, The University of Leeds, Leeds, UK

H Mielants, Department of Rheumatology, Ghent University Hospital,

Ghent, Belgium

\section{REFERENCES}

1 Clegg DO, Reda DJ, Weisman MH, Blackburn WD, Cush JJ, Cannon GW, et al. Comparison of sulfasalazine and placebo in the treatment of ankylosing spondylitis. A Department of Veterans Affairs Cooperative Study. Arthritis Rheum 1996;39:2004-12.

2 Clegg DO, Reda DJ, Abdellatif M. Comparison of sulfasalazine and placebo for the treatment of axial and peripheral articular manifestations of the seronegative spondylarthropathies: A Department of Veterans Affairs cooperative study. Arthritis Rheum 1999:42:2325-9.

3 Benitez Del Castillo JM, Garcia-Sanchez J, Iradier T, Banares A. Sulfasalazine in the prevention of anterior uveitis associated with ankylosing spondylitis. Eye 2000;14:340-3.

4 Gratacos J, Collado A, Filella X, Sanmarti R, Canete J, Llena J, et al. Serum cytokines (IL-6, TNF- $\alpha$, IL-1 $\beta$ and IFN $\gamma$ ) in ankylosing spondylitis: a close correlation between serum IL- 6 and disease activity and severity. $\mathrm{Br}$ J Rheumatol 1994;33:927-31

5 Braun J, Bollow M, Neure L, Seipelt E, Seyrekbasan F, Herbst H, et al. Use of immunohistologic and in situ hybridization techniques in the examination of sacroiliac joint biopsy specimens from patients with ankylosing spondylitis. Arthritis Rheum 1995;38:499-505.
6 Braun J Xiang J, Brandt J, Maetzel H, Haibel H, Wu P, et al. Treatment of spondylarthropathies with antibodies against tumour necrosis factor $\alpha$ : first clinical and laboratory experiences. Ann Rheum Dis 2000;59/suppl l):i85-9.

7 Braun J, Sieper J. The sacroiliac joint in the spondyloarthropathies. Curr Opin Rheumatol 1998;7:275-83

8 De Vos M, Cuvelier C, Mielants H, Veys E, Barbier F, Elewaut A. lleocolonoscopy in seronegative spondylarthropathy. Gastroenterology 1989;96:339-44

9 Mielants H, Veys EM, Cuvelier C, De Vos M. Course of gut inflammation in spondylarthropathies and therapeutic consequences. Ballieres Clin Rheumatol 1996:10:147-64.

10 May E, Marker-Hermann E, Wittig BM, Zeitz M, Meyer zum Buschenfelde KH, Duchmann R. Identical T-cell expansions in the colon mucosa and the synovium of a patient with enterogenic spondyloarthropathy. Gastroenterology 2000;1 19:1745-55

11 MacDonald TT, Hutchings P, Choy M, Murch S, Cooke A. Tumour necrosis factor-alpha and interferon-gamma production measured at the single cell level in normal and inflamed human intestine. Clin Exp Immunol 1990;81:301-5.

12 Murch SH, Braegger CP, Walker-Smith JA, MacDonald TT. Location of tumour necrosis factor alpha by immunohistochemistry in chronic inflammatory bowel disease. Gut 1993;34:1705-9.

13 Present DH, Rutgeerts P, Targan S, Hanauer SB, Mayer L, van Hogezand RA, et al. Infliximab for the treatment of fistulas in patients with Crohn's disease. N Engl J Med 1999:340:1398-405.

14 Targan SR, Hanauer SB, van Deventer SJ, Mayer L, Present DH, Braakman T, et al. A short-term study of chimeric monoclonal antibody cA2 to tumor necrosis factor alpha for Crohn's disease. Crohn's Disease cA2 Study Group. N Engl J Med 1997;337:1029-35.

15 Hanauer SB, Lichtenstein GR, Columbel J-F, Mayer L, Schreiber S, Rachmilewicz D. Maintenance infliximab (Remicade) is safe, effective and steroid-sparing in Crohn's disease: preliminary results from the Accent I trial [abstract]. Gastroenterology 2001;120:A-21.

16 Sandborn WJ, Hanauer SB, Katz S, Safdi M, Wolf DG, Baerg RD, et al. Etanercept for active Crohn's disease: a randomized, double-blind, placebo-controlled trial. Gastroenterology 2001;121:1242-6

17 Ritchlin C, Haas-Smith SA, Hicks D, Cappuccio J, Osterland CK, Looney RJ. Patterns of cytokine production in psoriatic synovium. J Rheumatol 1998;25: 1544-52

18 Partsch G, Steiner G, Leeb BF, Dunky A, Broll H, Smolen JS. Highly increased levels of tumor necrosis factor-alpha and other proinflammatory cytokines in psoriatic arthritis synovial fluid. J Rheumatol $1997 ; 24: 518-23$

19 Ettehadi P, Greaves MW, Wallach D, Aderka D, Camp RD. Elevated tumour necrosis factor-alpha (TNF-alpha) biological activity in psoriatic skin lesions. Clin Exp Immunol 1994;96:146-51.

20 Feldmann $M$, Brennan FM, Maini RN. Role of cytokines in rheumatoid arthritis. Annu Rev Immunol 1996; 14:397-440.

21 Antoni C, DeChant C, Ogilvie A, Kalden-Nemeth D, Kalden JR, Manger B. Successful treatment of psoriatic arthritis with infliximab in a MRI controlled study [abstract]. J Rheumatol 2000;27(suppl 59):24.

22 Ogilvie AL, Antoni C, Dechant C, Manger B, Kalden JR, Schuler G, et al. Treatment of psoriatic arthritis with antitumour necrosis factor-alpha antibody clears skin lesions of psoriasis resistant to treatment with methotrexate. Br J Dermatol 2001;144:587-9.

23 Mease PJ, Goffe BS, Metz J, VanderStoep A, Finck B, Burge DJ. Etanercept in the treatment of psoriatic arthritis and psoriasis: a randomized trial. Lancet 2000;356:385-90.

24 Yazici Y, Erkan D, Lockshin MD. A preliminary study of etanercept in the treatment of severe, resistant psoriatic arthritis. Clin Exp Rheumatol $2000 ; 18: 732-4$.

25 Maini R, St Clair EW, Breedveld F, Furst D, Kalden J, Weisman M, et al. Infliximab (chimeric anti-tumour necrosis factor alpha monoclonal antibody) versus placebo in rheumatoid arthritis patients receiving concomitant methotrexate: a randomised phase III trial. ATTRACT Study Group. Lancet 1999;354:1932-9.

26 Moreland LW, Schiff MH, Baumgartner SW, Tindall EA, Fleischmann $\mathrm{RM}$, Bulpitt $\mathrm{KJ}$, et al. Etanercept therapy in rheumatoid arthritis. A randomized, controlled trial. Ann Intern Med 1999:130:478-86.

27 Lipsky P, St Clair W, Furst D, Breedveld F, Smolen J, Kalden JR, et al 54-Week clinical and radiographic results from the ATTRACT trial: a phase III study of infliximab (Remicade ${ }^{\circledR}$ ) in patients with active RA despite methotrexate [abstract]. Arthritis Rheum 1999;42:S401.

28 Finck B, Martin R, Fleischmann R, Moreland L, Schiff M, Bathon J. A phase III trial of etanercept vs. methotrexate (MTX) in early rheumatoid arthritis (Enbrel ERA trial) [abstract]. Arthritis Rheum 1999;42:S1 17.

29 Siegert S, Yin Z, Radbruch A, et al. Evidence for a different cytokine secretion pattern of peripheral blood mononuclear cells of HLA B27+ patients with ankylosing spondylitis and HLA B27+ healthy controls compared to HLA B27-negative controls [abstract]. Arthritis Rheum 1998;41:S287

30 Canete JD, Martinez SE, Farres J, Sanmarti R, Blay M, Gomez A, et al. Differential Th1/Th2 cytokine patterns in chronic arthritis: interferon gamma is highly expressed in synovium of rheumatoid arthritis compared with seronegative spondyloarthropathies. Ann Rheum Dis 2000;59:263-8.

31 Yin Z, Siegert S, Neure L, Grolms M, Liu L, Eggens U, et al. The elevated ratio of interferon gamma-/interleukin-4-positive T cells found in synovial fluid and synovial membrane of rheumatoid arthritis patients can be changed by interleukin- 4 but not by interleukin-10 or transforming growth factor beta. Rheumatology (Oxford) 1999;38:1058-67. 
32 Baeten D, Van Damme N, Van den Bosch F, Kruithof E, De Vos M, Mielants $\mathrm{H}$, et al. Impaired Th 1 cytokine production in spondyloarthropathy is restored by anti-TNFalpha. Ann Rheum Dis 2001;60:750-5

33 Van Damme N, De Vos M, Baeten D, Demetter P, Mielants $H$ Verbruggen $G$, et al. Flow cytometric analysis of gut mucosal lymphocytes supports an impaired Th1 cytokine profile in spondyloarthropathy. Ann Rheum Dis 2001;60:495-9

34 Rudwaleit M, Siegert S, Yin Z, Eick J, Thiel A, Radbruch A, et al. Low T cell production of TNFalpha and IFNgamma in ankylosing spondylitis: its relation to HLA-B27 and influence of the TNF-308 gene polymorphism. Ann Rheum Dis 2001;60:36-42.

35 van der Linden S, van der Heidje D. Ankylosing spondylitis. Clinical features. Rheum Dis Clin North Am 1998;24:663-76.

36 Braun J, Yin Z, Spiller I, Siegert S, Rudwaleit M, Liu L, et al. Low secretion of tumor necrosis factor alpha, but no other Th1 or Th2 cytokines, by peripheral blood mononuclear cells correlates with chronicity in reactive arthritis. Arthritis Rheum 1999;42:2039-44

37 Van Damme N, De Keyser F, Demetter P, Baeten D, Mielants H, Verbruggen $G$, et al. The proportion of Th 1 cells, which prevail in gut mucosa, is decreased in inflammatory bowel syndrome. Clin Exp Immunol 2001;125:383-90.

38 Zou J, Rudwaleit M, Thiel A, Braun J, Sieper J. Downregulation of the non-specific and antigen-specific T cell cytokine response in ankylosing spondylitis after treatment with infliximab [abstract]. Arthritis Rheum 2001;44:S236.

39 Baeten D, Kruithof E, Van den Bosch F, Demetter P, Van Damme N, Cuvelier $C$, et al. Immunomodulatory effects of anti-tumor necrosis factor $\alpha$ therapy on synovium in spondylarthropathy. Histologic findings in eight patients from an open-label pilot study. Arthritis Rheum 2001:44:186-95.

40 Brandt J, Haibel H, Cornely D, Golder W, Gonzalez J, Reddig J, et al. Successful treatment of active ankylosing spondylitis with the anti-tumo necrosis factor alpha monoclonal antibody infliximab. Arthritis Rheum 2000;43:1346-2.

41 Brandt J, Haibel, H, Sieper J, Reddig J, Braun J. Infliximab treatment of severe ankylosing spondylitis: one-year followup [letter]. Arthritis Rheum 2001;44:2937.

42 Van den Bosch F, Kruithof E, Baeten D, DeKeyser F, Mielants H, Veys $E M$. Effects of a loading dose regimen of three infusions of chimeric monoclonal antibody to tumour necrosis factor $\alpha$ (infliximab) in spondyloarthropathy: an open pilot study. Ann Rheum Dis 2000;59:428-33.

43 Kruithof E, Van den Bosch F, Baeten D, Herssens A, De Keyser F, Mielants $\mathrm{H}$, et al. Repeated infusions of infliximab, a chimeric anti-TNFalpha monoclonal antibody, in patients with active spondyloarthropathy: one year follow up. Ann Rheum Dis 2002;61:207-12.

44 Mielants H. Treatment of refractory SpA/AS with TNF $\alpha$-blockers: the Belgian experience. Lecture presented at: International Workshop on New Treatment Strategies in Ankylosing Spondylitis; 18-19 January 2002; Berlin, Germany.

45 Stone M, Salonen D, Lax M, Payne U, Lapp V, Inman R. Clinical and imaging correlates of response to treatment with infliximab in patients with ankylosing spondylitis. J Rheumatol $2001 ; 28$ : 1605-14.

46 Collantes Estévez E. Treatment of refractory SpA/AS with TNF $\alpha$-blockers: the Spanish experience. Lecture presented at: International Workshop on New Treatment Strategies in Ankylosing Spondylitis; 18-19 January 2002; Berlin, Germany.
47 Breban M, Vignon E, Claudepierre P, Devauchelle V, Wendling D, Lespessailles $E$, et al. Efficacy of infliximab in refractory ankylosing spondylitis: results of a six-month open-labeled study. Rheumatology (Oxford) (in press).

48 Maksymowych WP, Jhangri GS, Lambert RG, Mallon C, Buenviaje $H$ Pedrycz E, et al. Infliximab in ankylosing spondylitis: a prospective observational inception cohort analysis of efficacy and safety. J Rheumatol 2002;29:959-65.

49 Braun J, Brandt J, Listing J, Zink A, Alten R, Krause A, et al. Treatment of active ankylosing spondylitis with infliximab-a double-blind, placebo-controlled multicenter trial. Lancet 2002;359:1 187-93.

50 Braun J. Treatment of refractory SpA/AS with TNF $\alpha$-blockers: the German experience. Lecture presented at: International Workshop on New Treatment Strategies in Ankylosing Spondylitis;18-19 January 2002; Berlin, Germany.

51 Van den Bosch F, Kruithof E, Baeten D, Herssens A, de Keyser F Mielants $\mathrm{H}$, et al. Randomized double-blind comparison of chimeric monoclonal antibody to tumor necrosis factor $\alpha$ (infliximab) versus placebo in active spondylarthropathy. Arthritis Rheum 2002;46:755-6.

52 Marzo-Ortega H, McGonagle D, O'Connor P, Emery P. Efficacy of etanercept in the treatment of entheseal pathology in resistant spondylarthropathy. Arthritis Rheum 2001;44:2112-17.

53 Gorman JD, Sack KE, Davis JC Jr. Treatment of ankylosing spondylitis by inhibition of tumor necrosis factor $\alpha$. N Engl J Med 2002;346:1349-56.

54 Spoorenberg A, de Vlam K, van der Heijde D, de Klerk E, Dougados $M$, Mielants $\mathrm{H}$, et al. Radiologic scoring methods in ankylosing spondylitis: reliability and sensitivity to change over one year. J Rheumatol 1999:26:997-1002.

55 MacKay K, Mack C, Brophy S, Calin A. The Bath Ankylosing Spondylitis Radiology Index (BASRI): a new, validated approach to disease assessment. Arthritis Rheum 1998;41:2263-70.

56 Averns HL, Oxtoby J, Taylor HG, Jones PW, Dziedzic K, Dawes PT Radiological outcome in ankylosing spondylitis: use of the Stoke Ankylosing Spondylitis Spine Score (SASSS). Br J Rheumatol 1996:35:373-6.

57 Braun J, Bollow M, Eggens U, Konig H, Distler A, Sieper J. Use of dynamic magnetic resonance imaging with fast imaging in the detection of early and advanced sacroiliitis in spondyloarthropathy patients. Arthritis Rheum 1994;37:1039-45.

58 Braun J, Bollow M, Sieper J. Radiology and pathology of the spondyloarthropathies. Rheum Dis Clin North Am 1998;24:697-735.

59 Bresnihan B, Alvaro-Gracia JM, Cobby M, Doherty M, Domljan Z, Emery $P$, et al. Treatment of rheumatoid arthritis with recombinant human interleukin-1 receptor antagonist. Arthritis Rheum 1998:41:2196-204.

60 Modigliani R, Mary J-Y, Simon J-F, Cortot A, Soule J-C, Gendre J-P, et al. Groupe D'Etude Thérapeutique Des Affections Inflammatoires Digestives. Clinical, biological, and endoscopic picture of attacks of Crohn's disease. Evolution on prednisolone. Gastroenterology 1990;98:811-18.

61 D'Haens G, Geboes K, Rutgeerts P. Endoscopic and histologic healing of Crohn's (ileo-) colitis with azathioprine. Gastrointest Endosc 1999;50:667-71

62 D'Haens G, Van Deventer S, Van Hogezand R, Chalmers D, Kothe C Baert F, et al. Endoscopic and histological healing with infliximab anti-tumor necrosis factor antibodies in Crohn's disease: a European multicenter trial. Gastroenterology 1999;1 16:1029-34, 